\title{
Article
}

\section{The work of the audience: visual matrix methodology in museums}

Froggett, Lynn, Muller, Lizzie and Bennett, Jill

Available at http://clok.uclan.ac.uk/28492/

Froggett, Lynn ORCID: 0000-0001-8406-6231, Muller, Lizzie and Bennett, Jill (2019) The work of the audience: visual matrix methodology in museums. Cultural Trends, 28 (2-3). pp. 162-176. ISSN 0954-8963

It is advisable to refer to the publisher's version if you intend to cite from the work. http://dx.doi.org/10.1080/09548963.2019.1617939

For more information about UCLan's research in this area go to http://www.uclan.ac.uk/researchgroups/ and search for < name of research Group>.

For information about Research generally at UCLan please go to http://www.uclan.ac.uk/research/

All outputs in CLoK are protected by Intellectual Property Rights law, including Copyright law. Copyright, IPR and Moral Rights for the works on this site are retained by the individual authors and/or other copyright owners. Terms and conditions for use of this material are defined in the policies page.

\section{CLoK}

Central Lancashire online Knowledge www.clok.uclan.ac.uk

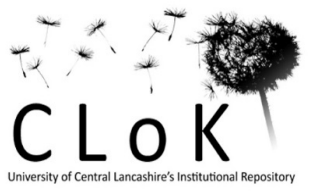


Froggett, L., Muller, L. and Bennett, J, (2019, accepted 14/05) The Work of the Audience:

Visual Matrix Methodology in Museums, Cultural Trends

\section{Lynn Froggett ${ }^{\mathrm{a}^{*}}$ Lizzie Muller $^{\mathrm{b}}$ and Jill Bennett ${ }^{\mathrm{c}}$}

${ }^{a}$ Institute for Citizenship, Society and Change, Psychosocial Research Unit, University of

Central Lancashire, UK, Lfroggett@uclan.ac.uk ${ }^{b}$ Faculty of Art \& Design, University of New

South Wales, Sydney, Australia 'Faculty of Art \& Design, University of New South Wales,

Sydney, Australia

Lynn Froggett has a Social Sciences/Humanities background. She researches socially engaged arts in clinical, community, cultural, arts and health and art-science contexts. Recent topics include memory loss, pain, disabilities, robotics, technology and civic renewal. She is Professor/CoDirector of the Institute for Citizenship, Society and Change at the University of Central Lancashire and Executive Chair of the Association for Psychosocial Studies.

Lizzie Muller is a curator and researcher specialising in interaction, audience experience and interdisciplinary collaboration. Her research explores the relationship between curatorial practice and shifts in contemporary knowledge formations, audience-centred curatorial methodologies, the impact of digital media on curating and museology and the history and future of museums as sites of knowledge creation.

Jill Bennett is Australian Research Council Laureate Fellow at the University of New South Wales (UNSW), where she is also Director of the National Institute for Experimental Arts, and Founding Director of The Big Anxiety - festival of arts + science + people. Her felt Experience \& Empathy Lab (fEEL) advances the study of the subjective experience of ageing, mental health, marginalisation and stigma, combining psycho-social approaches with the use of immersive environments and virtual reality. 


\title{
The Work of the Audience: Visual Matrix Methodology in Museums
}

\begin{abstract}
Visual matrix methodology has been designed for researching cultural imaginaries. It is an image-led, group-based method that creates a "third space" research setting to observe audience groups re-enacting lived experience of an event or process that takes place in the third space of a cultural setting. In this article the method is described through its use in relation to an art-science exhibition, Human + Future of the species, where three audience groups with investments in technology worked with exhibition material to achieve a complex, ambivalent state of mind regarding technological futures. The visual matrix has been designed to capture the affective and aesthetic quality of audience engagement in third space by showing what audiences $d o$ with what is presented to them. We argue that such methodologies are useful for museums as they grapple with their role as sites where citizens not only engage in dialogue with one another but actively re-work their imaginaries of the future.
\end{abstract}

\section{Keywords}

Visual matrix, third space, cultural imaginary, aesthetic third, civic museum

\section{Introduction}

This article introduces an image-led, group based method - the visual matrix - designed to enable researchers to study the aesthetic and affective aspects of audience experience that arise in the interaction between exhibitions and the cultural imaginaries of audience groups. Using visual matrix methodology to study audience responses to an art-science exhibition that showed in Singapore in 2017, Human + Future of the Species, we show how an exhibition experience can mobilise cultural imaginaries and how this can be captured in a visual matrix. Because it is a group 
sensitive method, attuned to affective and aesthetic impacts, the visual matrix enables a group to articulate felt experience in a social setting. ${ }^{1}$

Museum experience is filtered through and richly (re-)productive of cultural imaginaries which underlie the sense-making engagements of audiences as they relate what is presented in the museum to their own situation, and to the changing circumstances in which they live. We take imaginaries to be composed of the shared images and stories that infuse a common background understanding, so enabling communication and social practices (Taylor, 2004). They underlie meaning-making in groups or communities with respect to other people, the natural and man-made world, and the political, civic and moral order (Hall, 1997). Imaginaries are also implicated in the unconscious identifications and projections through which people fantasise their world as well as the symbolic realm in which they represent it (Lacan, 1973).

Museums are well positioned to create "third spaces" of connectivity and discursive exchange as well as fostering new "ecological" forms of cultural knowledge creation and collaborative practice (Cunningham, 2013; Stern \& Seifert, 2016). We align here with Simon's practice-focused work on museums as participatory spaces where new knowledge is produced in the active engagements between visitors and exhibitions (Simon, 2010). In this research project we have focused on museums that explicitly aim to bring together different disciplines particularly art and science. Such locations differ from other civic fora insofar as they are also sites of aesthetic experience (Muller, Froggett \& Bennett, 2018), which is central to the mobilisation of cultural imaginaries.

Despite its practical importance and intuitive deployment by curators, the nature of third space and what people do within it has remained elusive-difficult to conceptualise adequately, and hard to show "in action". In part this is because of a pervasive methodological individualism (Stern \& Seifert, 2016). An example is Crossick and Kaszynska's (2016) primary focus, on the "reflective and engaged citizen" when discussing cultural value. In our research we conceive museum third

\footnotetext{
1 The method was originally developed in the Psychosocial Research Unit at UClan, by Lynn Froggett, Alastair Roy and Julian Manley working with Michael and Claire Doherty from the arts organisation, Situations, Bristol (Froggett, Manley, Roy, Prior and Doherty 2014)
} 
spaces as physical, social and psychic spaces where people engage with exhibitions through a culture that is in some degree shared, in the real or imagined presence of one another. We have developed the visual matrix to understand them better, beginning with the principle that to study a third space researchers, together with participants, need to (re-)experience one. The visual matrix therefore creates a physical setting that enables a social group with a shared cultural imaginary to inter-subjectively re-enact an exhibition experience and to articulate it without recourse to expert art critical language, or after-the-event reflection.

The research example we use comes from an international project examining the value of spaces of collective imagination - third spaces that bring together art, science and the public (Muller, Froggett \& Bennett, 2018). The aims of this article are three-fold:

(1) Account for the active nature of aesthetic experience, shifting the emphasis from what exhibitions evoke in audiences to what audiences do with exhibitions;

(2) Show how the visual matrix enables a group to bring to mind and articulate the reconfiguration of a cultural imaginary through an exhibition experience;

(3) Clarify the nature of audience engagement in the third space of the museum, showing how museums can create civic third spaces

Below we highlight some acknowledged difficulties for researchers in studying aesthetic experience before describing the visual matrix as a psychosocial method that creates a third space to study audience engagement with a given exhibition. We return in our discussion to the implications for the role of museums as sites of civic encounter.

\section{Challenges in Researching Aesthetic Experience and Audience Engagement}

Belfiore \& Bennett (2007) summarise the research challenges of investigating aesthetic experience: it is regarded as overly subjective and hard to investigate scientifically (Molnar, 1974; Csikszentmihalyi \& Robinson, 1990); it is influenced by variables external to artwork and audience such as framing and titling (Levinson, 1985); empirical psychological aesthetics has too limited a conception of cognition (Parsons, 1987; Carey, 2005); language inadequately expresses 
aesthetic response (De Bolla, 2001); a mistrust of emotions (intrinsic to aesthetic experience) runs through Western culture (Wood \& Smith, 2004); much aesthetic engagement remains unconscious (Feagin, 1996; Belfiore \& Bennett, 2008). Belfiore and Bennett propose a complex interactive model of engagement that includes factors pertaining to the individual, artwork and environment, concluding that while existing research can "illuminate some of the basic cognitive and emotional mechanisms...it falls short of capturing the aesthetic experience in its totality and fails to account for its complexity and richness." (p. 261)

Similarly, Kirchberg and Troendle (2012) review studies of museum visitor experience and claim that where researchers have tackled this question, survey methods have addressed "the cognitive and linguistically processed echoes of previous experience, but not the experience itself ...What method could illuminate the experience of aesthetic presence, in addition to measuring other experiences?” (p. 448).

Since Belfiore and Bennett's article, investigation of aesthetic experience has evolved in material culture studies (see Dudley, 2010) but in much audience research two reductionist assumptions have prevailed: that experience can be usefully deconstructed into quantifiable categories and that the unit of analysis remains the individual, even though audiences are collectivities who encounter cultural objects "in-the-moment" in the real or imagined presence of one another. Nor do methods that ask questions after the event resolve the problem of articulating unconscious aspects of experience. Yet museums could be regarded as repositories of "the unthought known" (Bollas, 1987) providing through their exhibitions material that arouses inchoate anxieties and desires - for example relating to past and present identities and unknown futures.

The challenge therefore is to develop a methodology that does not regard museum visitors as socially atomised individuals, or depend on discursive accounts of experience after the event (as in a focus group $)^{2}$, but which offers experience-near re-enactment in an inter-subjective third

\footnotetext{
${ }^{2}$ See Froggett et al 2015 for an empirical comparison of results produced by a visual matrix and a focus group
} 
space. Under such conditions it becomes possible to see what audiences produce in relation to an exhibition, rather than what they think about it.

\section{The Visual Matrix in Human + Future of the Species}

Human+ The Future of our Species (hereafter referred to simply as Human +) featured the machinic and biological future of humankind in a changing technological environment that is transforming the conditions of survival. It was concerned with human relations to machines, cyborgs, other organisms, "inner" and "outer" nature, robotics, assistive technologies and bioengineering. It brought together work by 40 artists, technologists and designers to ask how technoscience is changing bodies, minds, relationships and habitats.

\section{Context and Recruitment}

In Singapore the ambitions of a prosperous city state are dependent on public participation in a knowledge economy of constant innovation. This future orientation sees humans as adaptive and perfectible bio-machines within a well-ordered environment of perpetual progress. There is a historical association in Singapore between progress and containment of the natural world (Barnard, 2014). Third spaces such as the ArtScience Museum are one of the few civic arenasin Singapore and elsewhere-where competing visions of scientific and technological development can combine to form new shared imaginaries.

With the help of museum staff and a Singaporean recruiter with local knowledge, we recruited three audience groups that are beneficiaries of technological development: interdisciplinary design students, robotics and biotechnology researchers/professionals and differently-abled adults. They therefore had educational, occupational and assistive investments in technology. The stated aim of the project was simply to understand their responses to Human + without specifying any particular focus. Invitations were issued to the students via their college and to the differently-abled group through disability organisations. The technologists were mainly Higher Education professionals, with two also identifying as artists. All participants volunteered and were proficient in English; a signer translated for a deaf participant. 
The unit of analysis in a visual matrix is the group. The method yields experiential and contextualised data and the greater the commonality of the group in relation to presented material, the clearer the results. Our groups were of similar size $(n=14-17)$; participants in each group had a similar position in relation to educational/labour market opportunities, but we aimed for a diversity within each group reflective of Singaporean society in respect of gender and ethnicity (Chinese, Malaysian and Indian heritage).

\section{Visual Matrix Process}

A visual matrix accommodates 6-30 members. Here there were 14-17 in each group, evenly divided between men and women. They spent up to an hour in the exhibition beforehand, singly or with colleagues, then they assembled in a comfortable room in the basement. Refreshments were available and the seating was arranged into a snowflake configuration that encourages people to speak into a shared space, rather than addressing one another (Figure 1.). This helps to avoid the alliances, confrontations, and power imbalances typical of group dynamics.

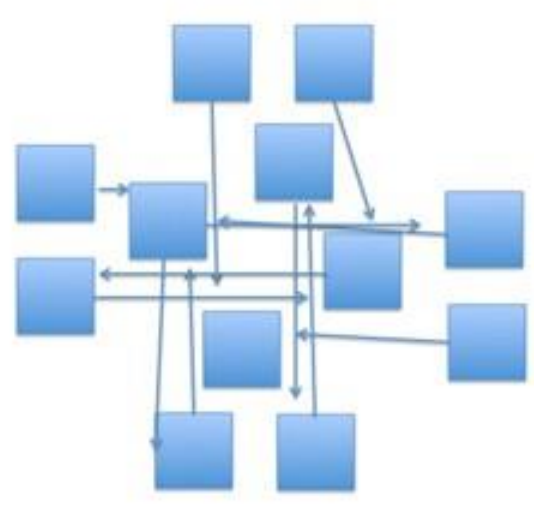

Figure 1. Snowflake Seating Configuration with chairs represented as squares and arrows showing direction of gaze 
Participants were informed that the matrix would run for 45 minutes and that after a short break they would image-map the proceedings and have the opportunity to question and discuss. During the matrix itself they could offer images, thoughts and feelings aroused by the exhibition or by one another's asociations, as and when they wanted, and without turn-taking. In this instance the visual stimulus for the matrix was the exhibition as a whole which was still very present in their minds. If a day or more had elapsed the matrix would have been brought back to mind by a sequence of photographic stills, mounted on a powerpoint presentation and watched slowly in silent contemplation. As is usual, the facilitators were seated in the matrix and participated to model the associative process, but not to lead or shape the content. Our Singaporean recruiter had expressed doubts as to whether participants would be forthcoming with visual associations. In fact the unfamiliarity of the matrix situation (in any cultural context) is important in diverting people from habitual modes of self-expression. Any initial inhibition was soon dispelled and all three groups engaged readily.

The aim is to establish an environment that encourages free association that Bion ([1962] 1970) described as "reverie". The matrix should operate as a "container"- - which is to say that it should favour a meditative, receptive consciousness and creative linking of ideas. Reverie resembles day-dreaming and Bion described it in metaphors of digestion and metabolism. Participants discover that image material that arises in one context sparks associations that lead off in unanticipated directions "nourishing" new ideas. Images are prompted by affective and sensory experiences within the group, but draw on personal and cultural life experiences. The students, for example, referred to family, education, relationships and their hopes and fears for a future world of work. The Singaporean context was explicit throughout-its hyper-competitiveness, and demands for continual adaptation. It was also evident in more subtle ways - affective responses to technology and fearful allusions to engulfment (the encroaching jungle) and Nature beyond human control.

Image associations in a visual matrix are affectively-laden and come from memories, dreams, landscapes, films or other cultural material. They form at times into clusters or nodes or branch out in rhizomatic rather than linear fashion-accumulating into a collectively-produced 
collage $^{3}$. Threads intertwine, sometimes receding only to re-emerge later. A matrix is never simply a series of singular image references - its subject matter is the exhibition as a whole in a museum environment. The facilitation discourages rationalisation or analysis. If thematic discussion, or long narratives occur a facilitator will offer an image to pull the matrix back into associative mode. Experience felt and enacted "in the moment" is prioritised and, because this is prompted by other participants' associations, it has a shared character.

In the post-matrix discussion that follows the break the chairs are re-arranged into a semicircle around a flip chart or white board. The group maps images produced by the matrix according to their priorities and criteria of relevance, identifying affective intensities, dominant ideas, and linkages between clusters. Participants thus establish the frame for a hermeneutic process that the researchers will complete, thus co-producing the results and safe-guarding against overinterpretation. The research team then works as a panel on the audio-recording and transcript. It was within the post-matrix discussions that the key organising idea of each group emerged (as shown below).

The panel analyis involves at least three further passes at the data-from experiencenearness to analytic distance, which also reflects the passage of time. The protocol is an adaptation of the depth hermeneutic method associated with cultural analyst Alfred Lorenzer (Lorenzer 1986; Salling Olesen 2013) ${ }^{4}$. In Figure 2. below the matrix is represented as the black dot at the narrow end of the hermeneutic vortex which runs through the whole process. The transcript of the matrix is the primary data to which the panel iteratively returns asking three kinds of question: substantive (what was presented?), performative (how was it presented?) and explanatory (why was it presented thus?). Although these modes of interrogating the data are represented in sequence, in practice they are intertwined. It is important to work first with the experience-near memory of the matrix (using devices that make it "present" such as reading aloud, uninterrupted recall, scenic composition (Froggett et al, 2014). Only then should the panel reach for explanation. In the final

\footnotetext{
${ }^{3}$ Associations branch, forming new clusters of imagery, "nodes" of ideas and affective intensities. The Deleuzian metaphor of the rhizome (Deleuze \& Guattari, 1988) captures the images, affects and ideas and non-linear thought processes of the visual matrix.

${ }^{4}$ Currently also associated with the International Research Group for Psychosocietal Analysis (Hollway and Volmerg, 2010)
} 
explanatory phase, relatively distant in time from the matrix, external experts or interested parties can be invited and implications for practice or policy discussed.

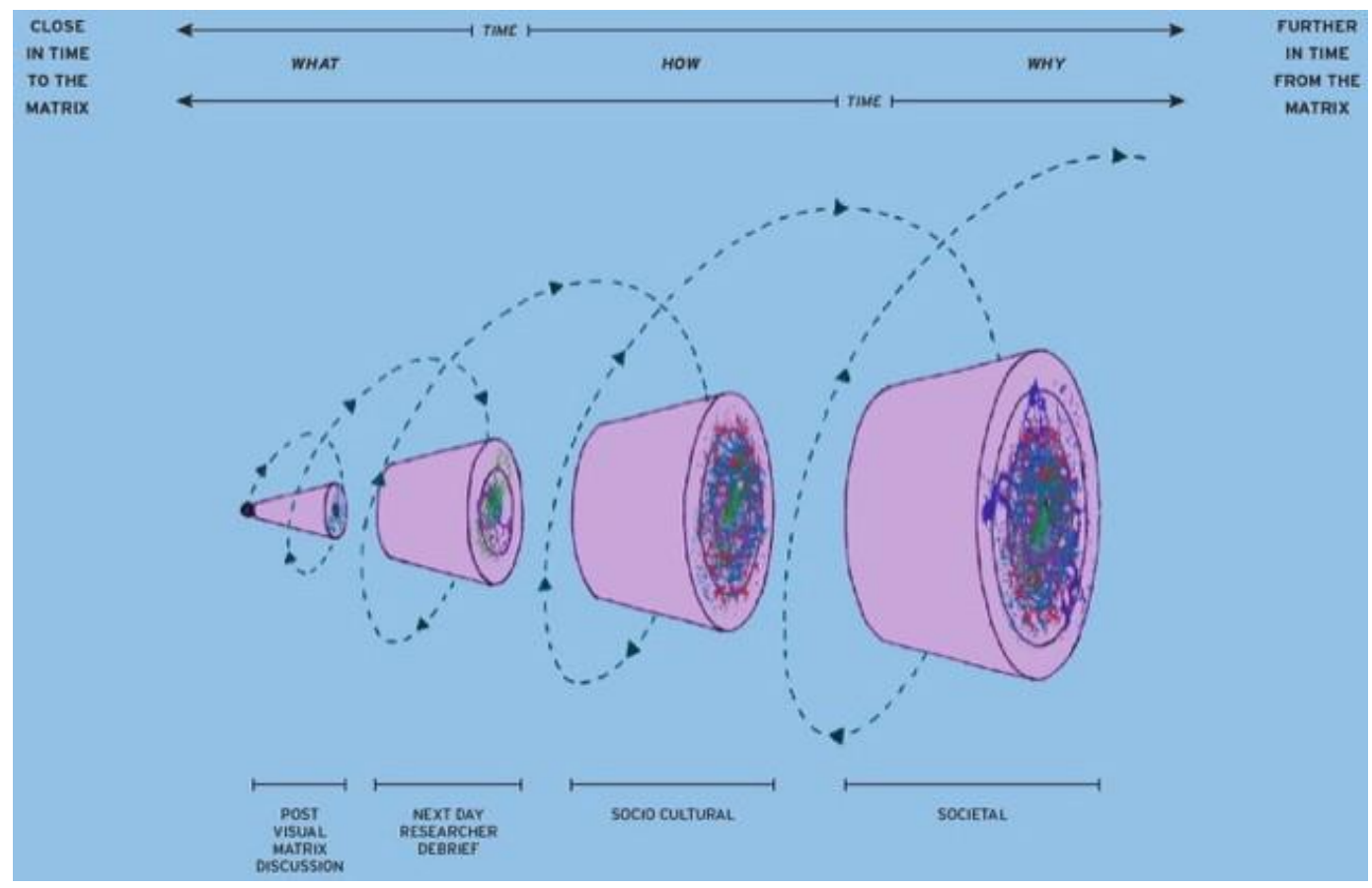

Figure 2. The Hermeneutic Vortex of Visual Matrix Analysis

\section{Findings}

Each matrix is rhizomatically interconnected-participants respond to the whole exhibition experience, selecting clusters of objects or ideas that are significant to them (supporting or diverging from curatorial decision-making). For example, silicone models of babies modifed for survival in a degraded environment ${ }^{5}$ caught the attention of each matrix, troubling its mood. Participants reacted to the sensory organisation of the exhibition (intended or otherwise), according to their situation-for instance the group with disabilities responded particularly to its

\footnotetext{
${ }^{5}$ Agatha Haines. (2013). Transfigurations [installation] see https://www.marinabaysands.com/museum/exhibition-archive/human-plus/life-edges.html
} 
kineasthetic qualities which they associated to impulsion by controlling forces, whether robotic or human.

Each of the three groups was ambivalent about adaptation and technology in their own way. However, the cultural imaginaries they drew on and elaborated become more anxious as associations proliferated. They did not talk directly about social and occupational position, rather they unconsciously cathected with elements of the show that resonated with their life experiences. Associations to different parts of the exhibition accumulated and combined, and for each group a signature metaphorically-expressed idea and mood emerged: for the students dejection at automated production lines; for the technologists fear of parasites and micro-organisms that will overwhelm humankind; for the group with disabilities anxiety at machinic alienation from feeling and being with one another.

\section{Group 1: Students - Coding in a Cave}

The students envisaged automated industrial work in which the complex intellectual and sensory tasks of designing and making that formerly demanded human skill, are undertaken by robots. It is a situation that is fast approaching, yet these young people think of themselves as training for occupations that demand inventiveness and creativity. The topic is much-discussed and apprehensive feelings about it circulate in Singaporean culture.

A fearful fascination at human enhancement pervades the matrix, beginning with prosthetics and associated to the superhuman — children hyper-trained for athletic performance and modified babies adapted for environmental stress. "Scary" is repeated throughout:

- Stretching humans to their maximum ability is very scary because like, that makes us question our surroundings... Like, is this the life that we want ... like how far has humanity come, I guess?

Following images of robotic cleaners in food courts, the group condenses layers of meaning and affect in the image of a future worker "coding in cave": 
- ...they were saying like the future of blue collar jobs would be coding. And then there was this image that they got - like an illustrator to portray of this cave like thing.... Like you would never have thought for the future blue collar job could have been coding something so automated, something so I guess, so less emotional.

- $\quad$ They don't interface with people, they just have to... what?

- I think they just have to code, they don't have to, lik, e face other people, because ultimately the code just goes inside the computer that's all.

- So boring.

Through this contemporary inflection of the iconic Platonic image, imprisoned in a cave, mistaking shadows for reality, the students symbolise the anxieties aroused by their future relation to worklife. They voice a personal sense of loss at the social and emotional deprivations of the cave, situating themselves (unwittingly) in relation to an archetype, and so transforming personal anxiety into communicable meaning — one of the functions of a cultural imaginary.

The image condenses an atavistic impulse "technology returns us to the cave"-and a future-oriented one- "how shall we live creatively?", together with a sense of sensory deprivation (lack of light, stupefaction of automation). The re-symbolised object creates a third position from which to think - neither caveman nor spaceman, but ambivalent humans bringing their relation to the present and future world of work vividly into thought. This third position thinking generates new ideas: the students ask themselves what kind of life they want and move beyond the binaries of past and future towards a complex social imaginary with which to navigate work-life dilemmas.

The image draws on personal biographical choices (to study design), the situation of the group (poised to enter the labour market), and on their "civic" roles, making use of the museum as a trans-disciplinary third space of reflection and exchange. 


\section{Group 2: Lived Experience of Disability_Fatal Rocking}

This matrix was pervaded by the existential crisis of assistive technologies that would "care for" humans whilst diminishing humanity. Rocking resonated: Stelarc rocked in his robotic arm, ${ }^{6}$ demeaningly, sadistically controlled, led on to re-engineered babies, bodies, empathy and deathall in the non-sentient grip of unthinking power

- A person is just turned and twirled and subjected to some big orange machine, I forget the colour but it looks orange, twisted and turned and lifted and sunk, as if we are, as if - making us feel helpless, not just people with disabilities, but rather human beings in general because we do not know who owns our bodies... is it a machine or is it really humanity, our own mind?

The euthanasia roller-coaster ${ }^{7}$ of social sci-fi design loops its riders, thrillingly, towards fatality. The idea is associated to the information society:

- $\quad$ and you are put into it, and it seems like a never-ending roller coaster ride and it comes to a point where you are just trying to tolerate it until you reach the end.

While machines adapt "defective" body parts for functional capacity, they promote a myth of infinite perfectibility, devaluing those who are different and who in a bio-engineered future may not be allowed to exist. Speaking of gene therapy and eliminating autism a participant observes:

- ...then Ifeel worthless as an individual as ... there would be no one with my struggles and I feel not as loved as a human being. Too scary.

${ }^{6}$ Stelarc. (2015). Propel: Body on Robot Arm [video 5m 29sec]

https://www.youtube.com/watch?v=2bRpTn0KKd8

${ }^{7}$ Julijonas Urbonas (2010). Euthanasia Coaster http://julijonasurbonas.lt/euthanasia-coaster/ 
Invoked here is the importance in human lives of loving and being loved by an adaptive human other who, values us for what makes us different. The robotically rocked cradle ${ }^{8}$ is:

- ... kind of like the emotional dissociation in that whole exhibition hall ...

- It takes the humanness out of us doesn't it? So when I saw it - it was just like - tears gushing out of my face ... failure is part of humanness so [if] we carry it and it does not comfort or make the baby sleep, at the very least the baby feels that someone is not carrying him the way he feels....

The image jars - adaptation in the parent-baby couple comes from being carried in the way that one feels in the arms and mind of a human mother. The unresponsive machine is a metaphor for society's failure to "carry" the people it disables so that they cannot feel themselves at ease within an adaptive, holding environment (Winnicott, 1971). At the same time, rocking imagery evokes for autistic participants a 'stimming' action, which would normally serve a self-soothing function but in this context amplifies a sense of stress.

\section{Group 3: Technologists-Creepy Looking Plants}

The technologists (on terra firma) begin with an air of detached amusement - noting the failed simulations of over-theatrical humanoids. Nadine, a life-like social robot, who resembles her creator $^{9}$ makes eye contact, greets people, remembers conversational partners, and gestures expressively, suggesting emotion. Yet her too large hands - sign of the maker rather than the made - attract disparagement

- Hands are a kind of giveaway or a clue to the artifice

\footnotetext{
${ }^{8}$ Addie Wagenknecht (2012). Optimisation of Parenting, Part 2 http://www.placesiveneverbeen.com/details/optimization-of-parenting-part-2 ${ }^{9}$ Institute for Media Innovation (IMI) Nanyang Technological University (NTU) Singapore (n.d.). Nadine [participatory installation] https://www.marinabaysands.com/museum/exhibition-archive/human-plus/lifeedges.html
} 
- ... farmer's hands - they were so big and rough

- I was distracted by her hair clip... why is she wearing that big dramatic clip with tassels on it....

Nadine is not simply failing to be a convincing human — she is failing to be a convincing woman. Humanoid robots are associated with ostentatious drag with affectations to help them "pass", whilst their social accomplishments - inadequate simulations of human interaction — render them somehow ridiculous. However, more disturbingly

- What I mainly kept thinking of with the robots was thermostats, building air-conditioning. All of these robots seem over-engineered for their tasks, but we're already surrounded by robots-we just don't notice them

- Mmmn ...

- .... Now I can't help imagining her [Nadine] having a conversation with an air conditioner (laughter)

The uncanny little bio-engineered babies are recalled and the matrix shifts to a troubled questioning of the moral limits of human adaptation. Body modification confounds participants with primitive jealousy mingled with revulsion-imposed "deformities" in a modern-day, clinically achieved, freak show. French artist Orlan's experiments with plastic surgery ${ }^{10}$ work to a similar end as does Stelarc's implantation of an ear on his forearm, also in the exhibition ${ }^{11}$.

The faces of the babies seemed to be in pain, like a lot of the artificial skin on the lips and the images of blood around the missing toe really stuck ...

\footnotetext{
${ }^{10}$ Orlan. (1994). Self-Hybridation, Entre-deux (Self-Hybridation, In-Between 1994) https://www.marinabaysands.com/museum/exhibition-archive/human-plus/augmented-abilities.html ${ }^{11}$ Nina Sellars. (2006-7). Oblique-Images from Stelarc's Extra Ear Surgery https://dublin.sciencegallery.com/humanplus/oblique-images-stelarc's-extra-ear-surgery/
} 
...It reminded me of pictures of little Chinese babies with bound feet, you know...

Biological hybridization crosses a subtle line-a worry begins to take hold ${ }^{12}$ :

- [he was working with] a human cell but yet, somewhere in the-the way that it has been treated in the lab, where it had been cut and re-cultured and re-cultured and re-cultured ... and it was suddenly classified as a pig even though it happened in a context with no pigs.

With this move to the cellular the ambivalence of the matrix becomes focalized on the contest between human and non-human "there's more bacteria than human cells". A fearfulness emerges of human interference with nature

- ...the artificial versus the natural what are we-what are we creating? Is it for good?

Detachment gives way to full-blown anxiety. The matrix is now haunted by post-human dystopia - nature as bacteria, parasites, micro-organisms will overwhelm and erase humankind. It is not technology that scares the technologists but how we meddle with forces beyond our control, that ultimately will exceed us. Humankind's destruction is within

- ....there's one parasite that infiltrates the brain of mice to make them not fear cats any more, so the cat will actually eat them and that weird parasite can continue its life-cycle

- toxoplasma gondii, I think

- isn't it Darwin's theory that says that it's the ones who can adapt that survive - not necessarily the most intelligent or the strongest.

\footnotetext{
12 Told in relation to Oron Katz and Ionat Zurr (2000). Semi-Loving Worry Dolls https://www.marinabaysands.com/museum/exhibition-archive/human-plus/life-edges.html
} 
The matrix begins to "metabolise" this thought — adaptation as slow extinction — symbolised by a shiny white coffin ${ }^{13}$ that processes the decomposing corpse through a bio-electric battery fuelled by its effluents. The body is returned to the elemental

- ...cycle of life, composting, creating new plants, but it's not the DNA you assume. It's just the-the recycling of carbon based matter.

- ..Like, batteries I get, [but] plants ... There's creepy looking plants out there!

Robots are old tech and will end with us_-our value lies in compost: death by plant in endless recycling.

\section{Discussion: Thirdness as Location, Relation and State of Mind}

We have characterised exhibitions as third spaces between a subjectively experienced world and a world objectively perceived - where audiences actively use their situation and life experiences to work with what is presented. Visual matrices are third spaces for re-enactment, created for methodological purposes. They are at once material settings (the snowflake and calm surroundings), arenas of real or imagined inter-subjective relations (expressed through association to one another's imagery) and they are set in motion by affective and aesthetic stimuli. Audience groups may use them to metabolise their exhibition experience. In so doing they produce a distinctive structure of feeling (Williams, 1981) and re-work their cultural imaginaries.

In order for this to happen the matrix must create containment - the conditions whereby initially inchoate or half-formed ideas find emergent symbolic expression in the imagery that the group creates. Participants undertake a transformative re-symbolisation of the images and ideas presented to them. Their recall of in-the-moment impressions of the exhibition is re-enacted in the here-and-now of the matrix and out of this aesthetic experience they produce new and original imagery and ideas that find expression not as discursive commentary, but in a visual or sensory

\footnotetext{
${ }^{13}$ James Auger and Jimmy Loizeau. (2009). Afterlife http://www.auger-loizeau.com/projects/afterlife
} 
symbolic register such "coding in a cave", "fatal dizziness", "creepy plants". This presentational symbolisation as Langer called it (1948 [1942]) arises out of a hitherto unexpressed unconscious embodied feeling, an unthought known for which the visual matrix groups find form through the associative process of the matrix. So it is that students find in the image of the coder an aesthetic third (Froggett \& Trustram, 2014) denoting neither subjective object (work imbued with their personal sense of loss) nor an objectively perceived object (automation as a socio-technical process $)^{14}$ but an object re-symbolised as "coding in a cave".

The process of finding aesthetic form for feeling is a work of aesthetic intelligence (Bennett Froggett \& Muller 2019) which in this instance brings cultural imaginaries of the future into thought. The signature metaphors that each of the groups collectively evolved in the course of their visual matrix are not mere representations - they are imagistic symbolic condensations that denote a shared state of mind: ambivalence towards technology and anxiety regarding what the future might hold. This anxiety reflects their particular cicumstances but the coding in a cave image also reflects a global and trans-historical consciousness.

By creating a setting in which participants associate to one another's associations, collaging their responses to the exhibition, the visual matrix enables them to bring personal life experiences into the frame - for example, the students refer to friends and family. They do so, however, not as privatised social atoms but by invoking a culture they hold in common with regard to familial relations. These are background assumptions through which the meaning and value of the artscience experience is registered. By foregrounding them in a communicative setting, the visual matrix more closely reflects the ways in which people talk and think about aesthetic experience than surveys or interviews that aggregate individualised responses. Herein also lies its principle limitation - the visual matrix cannot be a method of choice for researching the subjective experience of individuals. Nor does it offer a discursive forum where differences of attitude and opinion between individuals can be clearly distinguished.

\footnotetext{
${ }^{14}$ This distinction between subjective object ("for me") and object objectively perceived ("for itself") reflects Winnicott"s (1971) account of the tension between object qualities of "internality" and "externality" impelling the creation of a third through symbolisation.
} 


\section{The Civic Third of Museums}

There is an important role for museums in enabling audiences to re-imagine civic futures. Crossick and Kaszynska (2016) note that a growing body of studies show a correlation between cultural engagement and civic and pro-social behaviours but add that: "The relationship between cultural engagement and engaged citizenship is a difficult area to evidence" (2016, p. 58). They cite the Visual Matrix as offering an exploratory method "that takes us into the relationship between cultural participation and civic engagement in a more fine-grained way" (p. 62). In the UK assumed alignment between cultural and civil engagement underlies a "civic turn" among many local and regional museums (Latchford, 2018). This involves positioning themselves as anchor institutions, embedded in place, with the potential to broker new partnerships and collaborations. The American Alliance of Museums sees them as trusted "safe havens" where people can gather and converse (Long, 2013). However beyond their ability to make available heritage, sites and opportunities for exchange, our interest is in their civic role in mobilising cultural imaginaries rooted in aesthetic and affective experience.

Unlike the concept of community which can imply with a wish for transcendental unity, or polity which (in liberal democracies) is envisaged as an aggregate of potentially agonistic individuals - the civic is constituted by a mixture of local institutions and associations that support a public realm and the voluntary citizen engagement of civil society where "civility" entails a continual process of negotiating and accommodating otherness, or finding the similar in the other. Not for nothing is civil society nominated as "third sector". However, beyond social relations, the psychosocial concomitant of this thirdness is a state of mind and relationship that often remains unacknowledged. It depends on holding the individual and the collective in tension. Its thirdness therefore is neither individual nor social, but intersubjective and reflexively inter-dependent (Froggett, 2002). Thirdness, claims Britton (1998), involves a capacity "for seeing ourselves in interaction with others and for entertaining another point of view while retaining our own - for observing ourselves, while being ourselves (Britton 1998, p. 42)". Later, (writing of the humorous attitude in Haslitt's wanton self-mockery) he highlights a distinctly 
aesthetic aspect of observing and seeing that enables "laughing at ourselves while being ourselves" (Britton 2003, p. 143).

Evidential practices that are rooted in methodological individualism, such as interviews or focus groups reveal positionality but struggle to hold the tension between the individual and the social, revealing distinctions with clarity but not the "in-between" of third space. We support Crossick and Kaszynska's (2016) call for methodological pluralism in assessing cultural value. If the civic museum is to become an objective of cultural policy we also need methods that capture lived experience of culture and what audiences actively do individually and collectively in this space.

We see the individual-social tension held in a visual matrix session as participants associate to the aesthetic thirds presented, which they make sense of in terms of both personal situation and shared culture. Although we describe it as a group method, it is fair to say they enter the matrix as a number of disparate individuals and through the interweaving of their associations they arrive at shared patterns of experience. Together they elaborate and transform the aesthetic potentials of the exhibition into a re-worked imaginary. In doing so they do not efface their individuality in the service of groupthink - they draw continually on both subjective impressions and biographical material, but these are immediately incorporated into the rhizomatic structure of the matrix and give rise to a myriad of diverse associations in others, while the matrix works collectively towards an emergent whole. A distinctive group gestalt slowly emerges, expressed through ideation, aesthetic and structure of feeling. It is for this reason, perhaps, that despite the dystopian anxieties aroused by Human + all three groups in the end avoided binary thinking, neither idealising nor rejecting the technological futures they imagined. Instead they continued to offer images and ideas to a shared space, allowing them to sit alongside each other, diverge, or combine, until a common visual metaphor coalesced. They continued to work ambivalently with the questions: is this the life we want for ourselves? where does our responsibiliy lie? And what will it mean in the future to be human?

There are epistemic and practical as well as policy implications for arts institutions in recognising that their work consists in enabling active production of social imaginaries. This 
recognition should support curators in developing exhibitions that ground the future in the anxieties and desires of the present — creating third spaces in which the life experiences of individuals and groups encounter the stimuli that museums can offer for their re-imagining. As

museums move to become civic third spaces of dialogue and exchange ${ }^{15}$, which can contribute to the cultural renewal of ideas and social relations, they relinquish in some degree their epistemic authority as documenters of histories and cultures, in favour of co-creative work. The pay-off is in new forms of knowledge creation through the production of social and future imaginaries, to which they are uniquely positioned to contribute by providing the settings and opportunities for provocation, reflection, elaboration and re-symbolisation. Methodological innovation is required to mobilise the aesthetic intelligence of participant groups. The associative and sensuously grounded mode of visual matrix methodology aims to capture what audiences create as they engage in what Bhaba describes as the "borderline work of culture [that] demands an encounter with "newness". In re-enacting their responses to an exhibition in the third space of the matrix, they engage in an act of cultural translation that

"... renews the past, refiguring it as a contingent "in-between" space that innovates and interrupts the performance of the present. The past-present becomes part of the necessity, not the nostalgia of living." (Bhaba 1994, p.7)

\section{Acknowledgements}

This study was supported by the ArtScience Museum Singapore. Visual matrices and analysis included partners at various stages: Nina Ernst, Director Public Engagement, ArtScience Museum, Katie Dyer, Senior Curator, Contemporary, Museum of Applied Arts and Science, Rachel Perry, Research Fellow, Australia Council. Curating Third Space is supported by the Australian Research Council Linkage scheme and the Australian Government through the Australian Council, its arts funding and advisory body.

\footnotetext{
${ }^{15}$ See (Latchford, 2018)
} 
Barnard, T. P. (2014). Nature Contained: Environmental histories of Singapore. Singapore: NUS Press.

Belfiore, E., \& Bennett, O. (2008). The Social Impact of the Arts: An Intellectual History. London: Palgrave Macmillan.

Belfiore, E., \& Bennett, O. (2007). Determinants of Impact: Towards a Better Understanding of Encounters with the Arts. Cultural Trends, 16(3), pp. 225-275. doi:10.1080/09548960701479417 Retrieved from https://doi.org/10.1080/09548960701479417

Bennett, J., \& Froggett, L. (2019). Aesthetic Intelligence. In J. Bennett \& M. Zournazi (Eds.), Thinking in the world reader. London: Bloomsbury.

Bhaba, H. (1992) The Location of Culture. London: Routledge.

Bion, W. ([1962]1970). Attention and Interpretation. London: Tavistock.

Black, G. (2010). Embedding Civil Engagement in Museums. Museum Management and Curatorship, 25(2), pp. 129-146.

Bollas, C. (1987). The Shadow of the Object: Psychoanalysis of the Unthought Known London: Free Association Books.

Britton, R. (1998) Belief and Imagination, London Routledge.

Britton, R. (2003). Sex, Death and the Superego. London: Karnac.

Carey, J. (2005). What Good are the Arts? London: Faber \& Faber.

Csikszentmihalyi, M., \& Robinson, R. E. (1990). The Art of Seeing: An Interpretation of the Aesthetic Encounter. Los Angeles: https://eric.ed.gov/?id=ED388602

Crossick, G., \& Kaszynska, P. (2016). Understanding the Value of Arts and Culture: The AHRC Cultural Value Project. London: Arts and Humanities Research Council UK. https://irla.cat/wpcontent/uploads/2017/06/AHRC_Understanding the_value_of_arts_culture-A1.pdf.

Cunningham, J. (2013) Knitting Together Arts and Social Change. London: Royal Society of Arts https://www.thersa.org/globalassets/pdfs/reports/knitting-togetherarts-and-social-change-casestudy.pdf.

De Bolla, P. (2001). Art Matters. Cambridge, MA: Harvard University Press.

Deleuze, G., \& Guattari, F. (1988). A Thousand Plateaus. London: Continuum.

Dudley, S. (2010). Museum Materialities: Objects, Engagements, Interpretations. London: Routledge.

Feagin, S. L. (1996). Reading with Feeling: The Aesthetics of Appreciation. New York: Cornell University Press.

Froggett, L. (2002) Love, Hate and Welfare, Bristol: Policy Press.

Froggett, L. Manley, J., Roy, A., Prior, M. \& Doherty, C. (2014) Froggett, Lynn; Manley, Julian; Roy, Alastair; Prior, Michael \& Doherty, Claire (2014). Public art and local civic engagement. Arts and Humanities Research Council and University of Central Lancashire, Preston, UK, http://clok.uclan.ac.uk/10961/1/AHRC_CV20RDA_TOC_FINAL_2.pdf

Froggett, L., Manley, J., \& Roy, A. (2015). The Visual Matrix Method: Imagery and Affect in a Group-based Research Setting. Forum Qualitative Sozialforschung / Forum: Qualitative Social Research, 16(3), pp. 1438-5627.

Froggett, L., \& Trustram, M. (2014). Object Relations in the Museum: A Psychosocial Perspective. Museum Management and Curatorship, 29(5), pp. 482-497.

Hall, S. (1997). Representation: Cultural Representations and Signifying Practices London: Sage. 
Hollway, W., \& Volmerg, B. (2010). Interpretation Group Method in the Dubrovnik Tradition. International Research Group for Psycho-Societal Analysis. Retrieved from http://oro.open.ac.uk/34374/2/DubrIntGpMethodJune2010WH\%26BV.pdf

Kirchberg, V., \& Troendle, M. (2012). Experiencing Exhibitions: A Review of Studies on Visitor Experiences in Museums. Curator: The Museum Journal, 55(4), pp. 435-451. Lacan, J. (1973). The Four Fundamental Concepts of Psychoanalysis (A. Sheridan, Trans.) Harmondsworth, London: Penguin.

Langer, S. K. (1948). Philosophy in a New Key: A Study in the Symbolism of Reason, Rite, and Art New York: NAL Mentor.

Latchford, P. (2018). A New Enlightenment: Strengthening Civic Museums. https://www.nationalmuseums.org.uk/news/new-enlightenment-strengthening-civicmuseums/

Levinson, J. (1985). Titles. Journal of Aesthetics and Art Criticism, 44(1), pp. 29-39. Lorenzer, A. (1986). Tiefenhermeneutische Kulturanalyse. In Lorenzer, Alfred (Ed.) Kultur-Analysen: Psychoanaltyische Studien zur Kultur (pp. 11-98). Frankfurt: Fischer

Molnar, F. (1974). Experimental Aesthetics or the Science of Art. Leonardo, 7(1), pp. 2326.

Muller, L., Froggett, L., \& Bennett, J. (2018). Emergent Knowledge in the Third Space of Art-Science. Leonardo. Retrieved from https://www.mitpressjournals.org/doi/abs/10.1162/leon_a_01690

Parsons, M. J. (1987). How We Understand Art: A Cognitive Developmental Account of Aesthetic Experience. Cambridge, UK: Cambridge University Press

Pearce, M. T., Zaidel, D. W., Vartanian, O., Skov, M., Leder, H., \& Nadal, M. (2016). Neuroaesthetics: The Cognitive Neuroscience of Aesthetic Experience. Perspectives on Psychological Science, 11(2), pp. 265-279.

Salling Olesen, H. (2013). The Societal Nature of Subjectivity: An Interdisciplinary Methodological Challenge. Forum Qualitative Sozialforschung / Forum: Qualitative Social Research, 13(3)doi:doi:http://dx.doi.org/10.17169/fqs-13.3.1908

Silvia, P. J. (2009). Looking Past Pleasure: Anger, Confusion, Disgust, Pride, Surprise, and Other Unusual Aesthetic Emotions. Psychology of Aesthetics, Creativity, and the Arts, 3(1), pp. 48-51

Simon, N. (2010). The Participatory Museum. Santa Cruz, California: Museum 2.0.

Steger, M. B. (2008). The Rise of the Global Imaginary: Political Ideologies from the French Revolution to the Global War on Terror. Oxford: Oxford University Press USA.

Stern, M., \& Seifert, S. (2009). Civic Engagement and the Arts: Issues of Conceptualization and Measurement. Philadelphia: Arts and Civic Engagement Impact Initiative of Americans for the Arts/ Animating Democracy.

Stern, M., \& Seifert, S. (2016). Understanding the Value of Arts and Culture: The AHRC Cultural Value Project by Geoffrey Crossick and Patrycja Kaszynska Cultural Trends, 25(4), pp. 277-279

Taylor, C. (2004). Modern Social Imaginaries. Durham and London: Duke University Press

Williams, R. (1981). The Sociology of Culture. Chicago: University of Chicago Press. Winnicott, D. (1971). Playing and Reality. London: Tavistock 
Wood, N., \& Smith, S. J. (2004). Instrumental Routes to Emotional Geographies. Social and Cultural Geography, 5(4), pp. 533-548 